Limnol. Rev. (2014) 14,3: 131-144

DOI 10.1515/limre-2015-0003

\title{
Optical properties of Polish lakes: the Secchi disc transparency
}

\author{
Dariusz Borowiak \\ Department of Limnology, University of Gdańsk, Bażyńskiego 4, 80-952 Gdańsk, Poland, e-mail: geodb@univ.gda.pl \\ Limnological Station in Borucino, 83-323 Kamienica Szlachecka, Borucino, Poland
}

\begin{abstract}
The spatial variation of water transparency of the largest Polish lakes was presented on the basis of documentary material collected by the Voivodeship Inspectorates for Environment Protection as well as university geography departments in the period of 1991-2013. Seasonal results of the Secchi disc measurements (spring, summer) for 706 lakes were gathered. This is more than 68\% of the total number of Polish lakes with a surface area larger than 50 ha. The mean water transparency of these lakes was $1.87 \mathrm{~m}$, while the median was $1.58 \mathrm{~m}$. Distinct inter-regional differences of the Secchi disc transparency were found, and it was also possible to distinguish three relatively homogeneous groups of macroregions where lakes have different optical characteristics. They can be divided into areas with lakes with high $(3.05 \mathrm{~m})$, medium $(1.99-2.11 \mathrm{~m})$ and low $(1.22-1.52 \mathrm{~m})$ water transparency. The Secchi disc transparency of these lakes was also analysed in relation to concentration values of the main forms of the optically significant constituents of water (coloured dissolved organic matter, suspended matter). The mean transparency of turbid, stained and clear lakes was, respectively, 1.16, 2.02, and $2.92 \mathrm{~m}$. Moreover, regional empirical models to predict Secchi disc transparency from chlorophyll $a$ concentration were also developed. It was assumed that inter-regional differences between models could be due to the probably different time of the ice sheet recession. The influence of the lake morphometry was most fully reflected in the impact of the depth conditions.
\end{abstract}

Key words: Secchi disc transparency, optically significant constituents, trophic state, lake basin morphometry, northern Poland

\section{Introduction}

Studies of the optical properties of lake waters are one of the classical studies in physical limnology. Systematic observations of lake water colour and measurements of its transparency were started in the second half of the nineteenth century by F.-A. Forel $(1877,1895)$, the father of the science of lakes - limnology. Soon similar observations were conducted in the lakes of Austria (Liburnau 1898), France (Delebecque 1898), Germany (Zacharias 1896; Ule 1898, 1901; Halbfass 1901), Sweden (Nordquist 1910; Ekman 1915), Italy (Garbini 1897), Africa (Hassert 1912), North America (Birge and Juday 1912, 1933) and Central America (Meek 1908; Juday 1915).

The first papers discussing the transparency issues of Polish lakes, i.e. within the modern-day state borders, appeared at the beginning of the twentieth century. Special attention should be paid to the papers of the German geographers mentioned above, Ule (1898) and Halbfass (1901), where the Masurian and Pomeranian lakes were described, as well as the work by Sawicki and Minkiewicz (1909) on the Tatra lakes. In the inter-war period comparative studies of water transparency and colour were conducted on the lakes of the Suwałki Lakeland (Lityński 1926; Stangenberg 1936) and, again, in lakes of the Tatra Mountains (Szaflarski 1936).

Intensive development of limnological studies, which started in the second half of the twentieth century in many Polish scientific and academic centres, as well as the launch of state monitoring of lake water quality, have contributed to increased knowledge of the hydrooptics of Polish lakes and the natural conditions of the diversity of their optical properties. In addition, these studies have allowed extensive documentary material to be collected in the field of spatial variability of the transparency of lake waters, the measurement of which was traditionally performed using a Secchi disc.

Water transparency is one of the physical properties of lakes which are the easiest to measure. In terms of the inland water ecosystems, its value is defined using a standard white plate of a diameter of 
about 20-30 cm, known as a Secchi disc. In order to standardise the measurements, which basically means establishing a uniform background against which a comparison of the apparent contrast of the object is made, alternative discs in the modification of Whipple (1899) are used. These discs have alternately white and black quadrants. The measurement of the water transparency with the Secchi method relies on defining the depth at which the contrast disappears between the object (disc) and the background (water column above the bottom) against which it is observed. This depth is called the Secchi disc visibility or just the Secchi depth. The Secchi depth, thus, is a function of the light reflection from the white plate. Most of all, this depth is conditioned by the total attenuation of the direct radiation beam, because for the image to arise the light must pass directly from the object to the observer's eye. In terms of the spectral analysis, water transparency refers to the average value, over the entire visible light range, of the absorption and scattering of solar radiation by water and its admixtures contained in the water column specified by the Secchi depth.

Despite many objections challenging the accuracy and objectivity of the measurements performed with the use of a Secchi disc (Preisendorfer 1986), this method is still widely used in limnological practice, both because of the simplicity of the measurements as well as due to the development of a number of regionally or more universally significant operational algorithms linking transparency with the concentration of the optically significant constituents of water (e.g. chlorophyll $a$, dissolved organic matter) (Schindler 1971; Edmondson 1980; Tilzer 1988; Koenigs and Edmundson 1991; Borowiak 2005) or the maximum depth of colonisation by submersed aquatic plants (Chambers and Kalff 1985; Caffrey et al. 2007). The results of the measurements of water transparency also allow fast, although only approximate, evaluation of other apparent optical properties of water (i.e. depending both on the medium properties and on the directional structure of the ambient light field). Such characteristics include the depth of the euphotic zone (Koenigs and Edmundson 1991; Borowiak 2011; Luhtala and Tolvanen 2013) and the diffuse attenuation coefficients (Arst et al. 2008; Padial and Thomaz 2008; Borowiak 2011; Ficek 2013), as well as other measures derived from them. Furthermore, in standard lake monitoring the Secchi disc depth, together with the concentration values of the chlorophyll $a$ pigment and phosphorus, is a commonly used parameter to control the eutrophication of lakes and their trophic status (Dillon and Rigler 1975; Carlson 1977; Hillbricht-Ilkowska and Kajak 1986; Erlandsson and Stigebrandt 2006).

\section{Research methods and study area}

The presented spatial variation of water transparency of the largest lakes in Poland was based on the documentary material collected in the framework of the state lake water quality monitoring conducted by the Voivodeship Inspectorates for Environment Protection as well as geography departments at universities and research institutes dealing with limnological issues and protection of lacustrine ecosystems. As a result of the research performed, seasonal results (spring, summer) of water transparency measurements for 706 lakes were gathered (Fig. 1). In terms of the number, it is more than $68 \%$ of the total number of Polish lakes with a surface area larger than or equal to 50 ha (according to Jańczak 1996, 1997, 1999). As the starting material for further comparative analysis the mean transparency values of both seasons (most measurements were conducted in April and August), established for the positions located in the deepest part of each lake, were selected. The concentration of optically significant constituents suspended and dissolved in the lake waters shows clearly-evident seasonal variations caused by periodic changes in the intensity and amount of the primary production of lakes, changes in the volume of the load of organic and mineral matter supplied from the catchment as well as seasonality of the thermodynamic processes occurring in the lakes. As a consequence, the optical properties of the lake waters are also subject to seasonal changes. In most cases, in the lakes of the temperate zone, the lowest transparency is observed in spring at the time of diatomaceous blooms, or in summer when there are green and/or blue algae blooms. Only in the case of lakes strongly coloured with dissolved organic matter (humic substances) is seasonality less visible because of the generally low water transparency of dystrophic lakes' water. Thus, the spring and summer water transparency measurements used in the analysis reflect the worst optical properties of the studied lakes (Fig. 2).

Due to the spatial extent of the area in question and the need to include as many of the lakes as possible, the study includes the monitoring data conducted primarily in the base period spanning the decade of 


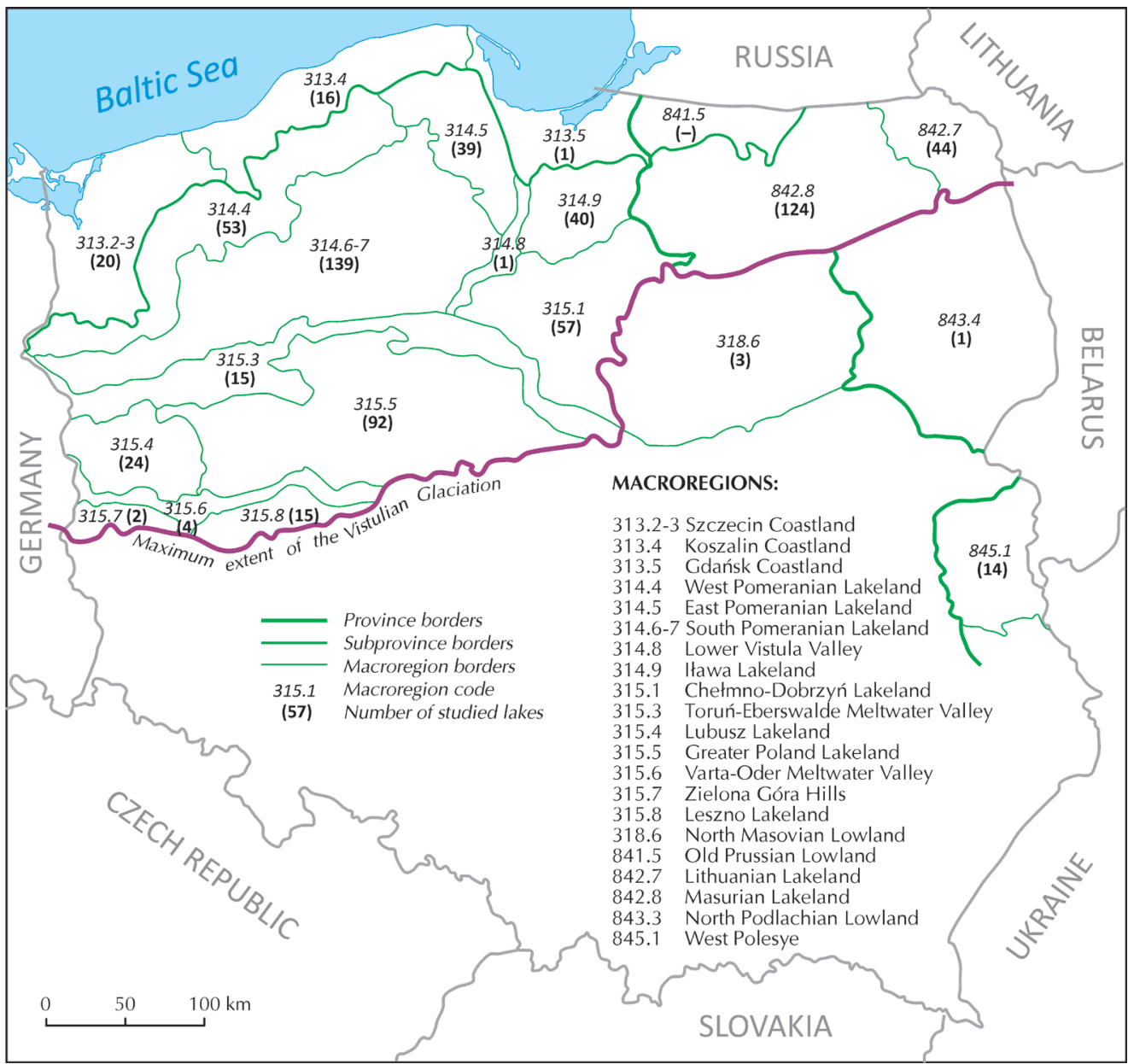

Fig. 1. Study area against the physicogeographical regionalisation of northern Poland (according to Kondracki 2011). Figures given in parenthesis after the region code denote the number of studied lakes within this region

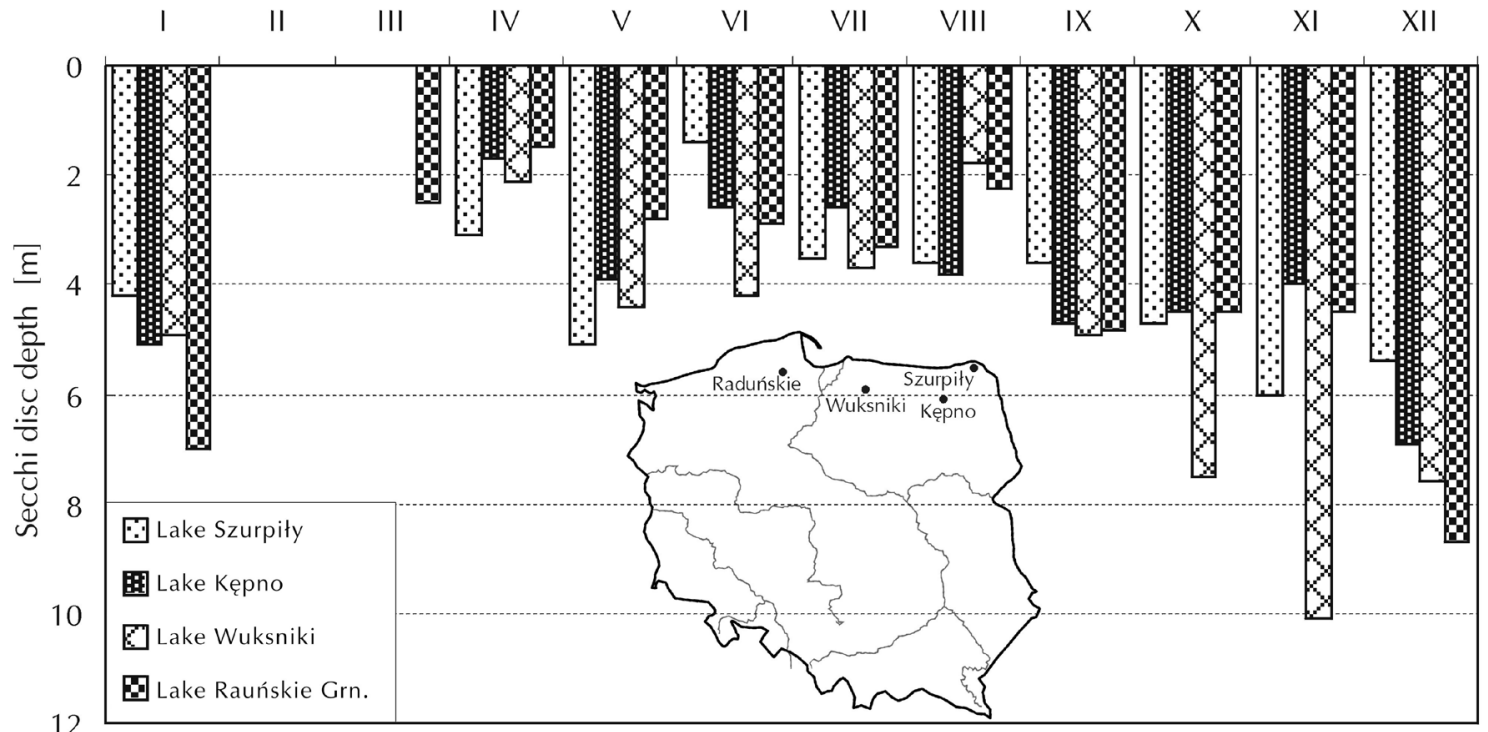

Fig. 2. Variability of the Secchi disc transparency of the selected lakes: Szurpiły (Lithuanian Lakeland - East Suwałki Lakeland), Kępno (Masurian Lakeland - Masurian Plain), Wuksniki (Masurian Lakeland - Olsztyn Lakeland) and Raduńskie Górne (East Pomeranian Lakeland - Kashubian Lakeland) in 2011 
2001-2010. The measurements from earlier years are taken into account only in the case where there are no measurement results from the base period, but the results of previously conducted investigations exist. The definite lower time limit for the data collected was the year 1991. Eventually, data from the following measurement periods were collected: the years 1991 to 1995 - for $4.3 \%$ of the total number of the analysed lakes; $1996-2000$ - for $9.6 \%$ of the number of the lakes; $2001-2005$ - for $32.0 \%$ of the number of lakes; $2006-2010$ - for $29.7 \%$ of the lakes; and after 2010 - for $24.4 \%$ of the lakes surveyed. Table 1 provides a detailed list of the percentage participation of the number, surface area and total water capacity of the lakes included in this study in relation to the total number of the largest lakes of Poland by physicogeographical regions (subprovinces, macroregions).

\section{Results}

The mean water transparency in the analysed group of the largest lakes of Poland, expressed by the Secchi disc depth, was $1.87 \mathrm{~m}$, while the median value was $1.58 \mathrm{~m}$. At the same time, the mean standard error of the mean value estimate was $0.045 \mathrm{~m}$ and a range around the median which covered $50 \%$ of the central results of the measurements (so called interquartile range) was determined by the depths 0.95 and 2.60 $\mathrm{m}$. From this review of the basic descriptive statistics it can be concluded that the transparency of Polish lakes is relatively low. Only in 176 of the lakes considered was the Secchi disc observed at depths greater than the upper quartile value amounting to $2.60 \mathrm{~m}$. The total range of variation of transparency, in turn, is determined by the extreme values of the analysed

Table 1. Absolute and relative number, water surface area (ha) and volume $\left(\mathrm{hm}^{3}\right)$ of lakes against the division into physicogeographical regions (subprovinces and macroregions) for the Polish lakes of 50 ha or more, in which the measurements of the Secchi disc depth were conducted

\begin{tabular}{|c|c|c|c|c|c|c|c|c|c|}
\hline \multirow[t]{2}{*}{ Region } & \multicolumn{3}{|c|}{ Number of lakes } & \multicolumn{3}{|c|}{ Surface area } & \multicolumn{3}{|c|}{ Volume } \\
\hline & total & studied & $\%$ & total & studied & $\%$ & total & studied & $\%$ \\
\hline South Baltic Coastlands & 44 & 37 & 84.1 & 28175.7 & 26704.8 & 94.8 & 1267.48 & 1241.06 & 97.9 \\
\hline Szczecin Coastland & 24 & 20 & 83.3 & 7817.8 & 7433.5 & 95.1 & 805.41 & 798.18 & 99.1 \\
\hline Koszalin Coastland & 19 & 16 & 84.2 & 18911.9 & 17825.3 & 94.3 & 444.72 & 425.53 & 95.7 \\
\hline Gdańsk Coastland & 1 & 1 & 100 & 1446.0 & 1446.0 & 100 & 17.35 & 17.35 & 100 \\
\hline East Baltic Coastlands & 5 & 2 & 40.0 & 685.1 & 179.3 & 26.2 & 10.72 & 2.78 & 25.9 \\
\hline South Baltic Lakelands & 651 & 481 & 73.4 & 106323.1 & 87640.9 & 82.4 & 7063.14 & 5920.03 & 83.8 \\
\hline West Pomeranian Lakeland & 91 & 53 & 58.2 & 14812.1 & 10477.2 & 70.7 & 1326.11 & 1066.78 & 80.4 \\
\hline East Pomeranian Lakeland & 39 & 39 & 100 & 5305.0 & 5305.0 & 100 & 414.66 & 414.66 & 100 \\
\hline South Pomeranian Lakeland & 199 & 139 & 69.9 & 32318.7 & 25409.9 & 78.6 & 2371.36 & 1846.79 & 77.9 \\
\hline Iława Lakeland & 51 & 40 & 78.4 & 12054.1 & 11037.6 & 91.6 & 540.16 & 493.95 & 91.5 \\
\hline Chełmno-Dobrzyń Lakeland & 62 & 57 & 91.9 & 8872.9 & 8296.0 & 93.5 & 552.51 & 526.55 & 95.3 \\
\hline Lubusz Lakeland & 28 & 24 & 85.7 & 3708.2 & 3280.3 & 88.5 & 254.23 & 231.95 & 91.2 \\
\hline Greater Poland Lakeland & 128 & 92 & 71.3 & 22432.4 & 18663.2 & 83.2 & 1341.74 & 1140.98 & 85.0 \\
\hline Leszno Lakeland & 21 & 15 & 71.4 & 3311.2 & 2854.6 & 86.2 & 132.40 & 123.42 & 93.2 \\
\hline Zielona Góra Hills & 3 & 2 & 66.7 & 255.7 & 203.6 & 79.6 & 2.70 & 1.32 & 48.9 \\
\hline Toruń-Eberswalde Meltwater Valley & 22 & 15 & 68.2 & 2469.9 & 1543.1 & 62.5 & 97.31 & 49.78 & 51.2 \\
\hline Varta-Oder Meltwater Valley & 6 & 4 & 66.7 & 622.0 & 409.5 & 65.8 & 22.93 & 16.82 & 73.4 \\
\hline Lower Vistula Valley & 1 & 1 & 100 & 160.9 & 160.9 & 100 & 7.03 & 7.03 & 100 \\
\hline East Baltic Lakelands & 308 & 168 & 54.5 & 95084.3 & 71822.4 & 75.5 & 8021.80 & 6423.48 & 80.1 \\
\hline Lithuanian Lakeland & 63 & 44 & 69.8 & 12037.4 & 10105.2 & 84.0 & 1339.13 & 1188.52 & 88.8 \\
\hline Masurian Lakeland & 245 & 124 & 50.6 & 83046.9 & 61717.2 & 74.3 & 6682.67 & 5234.96 & 78.3 \\
\hline Polesye & 14 & 14 & 100 & 1381.0 & 1381.0 & 100 & 64.47 & 64.47 & 100 \\
\hline Central Polish Lowlands & 7 & 3 & 42.9 & 802.8 & 424.3 & 52.9 & 39.02 & 27.53 & 70.6 \\
\hline Saxony-Lusatian Lowlands & 1 & - & - & 100.5 & - & - & 3.93 & - & - \\
\hline \multirow[t]{2}{*}{ Podlachian-Belarusian Heights } & 1 & 1 & 100 & 235.6 & 235.6 & 100 & 6.22 & 6.22 & 100 \\
\hline & 1031 & 706 & 68.5 & 232785.5 & 188388.3 & 80.9 & 16476.78 & 13685.56 & 83.1 \\
\hline
\end{tabular}


data set, namely $0.20 \mathrm{~m}$ (Lake Liwia Łuża) and 7.20 m (Lake Białe Wigierskie and Lake Ostrowite). These are mean values of transparency, defined on the basis of the measurements taken in two periods: spring and summer. Due to the aforementioned seasonal variation of the composition, ratio and concentration of the optically significant constituents of the lake water, the absolute transparency maxima show a much wider range of variation.

The lowest values of the Secchi disc depth among the lakes of the Polish Lowland, amounting to $0.10 \mathrm{~m}$, are found in Lake Liwia Łuża (Szczecin Coastland) and Lake Tonowskie (Greater Poland Lakeland). In the case of these lakes such extremely low water transparency was caused by excessive concentration of suspensoids, mostly organic matter (chlorophyll $a$ concentrations of above $90 \mathrm{mg} \mathrm{m}^{-3}$ ). Indirectly, the low water transparency of these lakes was undoubtedly influenced by the extremely unfavourable depth characteristics, favouring the resuspension of the mineral and organic particles previously deposited in the bottom sediments. These lakes show one of the lowest mean depths in the entire study group of lakes, respectively, $0.9 \mathrm{~m}$ (Lake Liwia Łuża) and $1.9 \mathrm{~m}$ (Lake Tonowskie). A significant role of the resuspended matter in shaping the water transparency of these lakes is also supported by the above-average concentrations of nutrients present in the surface layer of the water, especially of phosphorus, the mean concentration of which in those water bodies significantly exceeds 0.50 $\mathrm{mg} \mathrm{P} \mathrm{dm}{ }^{-3}$. In turn, the greatest depths of the Secchi disk visibility (often exceeding $10 \mathrm{~m}$ ), identified on the basis of the seasonal measurements, were noted, inter alia, in Lake Hańcza (Lithuanian Lakeland), 11.8 m, and Lake Wuksniki (Masurian Lakeland), $10.1 \mathrm{~m}$ (Fig. 2).

The cases of lakes in which the maximum annual values of transparency exceed $8 \mathrm{~m}$ were also quite common. This group includes the following lakes: Raduńskie Górne (East Pomeranian Lakeland) - 8.7 m; Budzisławskie (Greater Poland Lakeland) - 8.5 m; and Ostrowite (South Pomeranian Lakeland) $-8.5 \mathrm{~m}$. The case of Lake Raduńskie demonstrates that even the lakes that in the spring-summer season show a mean water transparency only slightly exceeding the value of the quartile $75 \%(2.60 \mathrm{~m})$, in the phase of the total ice cover or in the period preceding the stabilisation of the permanent ice cover, may show much greater water transparency and the Secchi disc depths higher than $8.0 \mathrm{~m}$ (Fig. 2).
The spatial variation of water transparency of Polish lakes shows some regularity. It is possible to distinguish three relatively homogeneous areas where lakes have different optical characteristics. By convention, they can be divided into areas with lakes with high, medium and low water transparency, but depending on the adopted criterion of the spatial division the individual territorial units will be assigned different guiding characteristics of transparency. Among the physicogeographical units in the macroregional rank only the Lithuanian Lakeland has the largest number of lakes with relatively high transparency (Fig. 3). Its mean value for the lakes of this macroregion, amounting to $3.05 \mathrm{~m}$, is over $63 \%$ higher than the mean calculated for the entire group of the studied Polish lakes. What is more, $75 \%$ of the lakes of this macroregion have higher transparency than the national mean. Such high transparency of lakes located within the Lithuanian Lakeland is shaped primarily by the small concentration of suspensoids, mainly phytoplankton suspension. The mean concentration of chlorophyll $a$ in the group of lakes of this macroregion is the lowest and amounts to $8.8 \mathrm{mg} \mathrm{m}^{-3}$. An additional factor in the above-average transparency of the lake water in the Lithuanian Lakeland is the favourable morphometry of the lake basins. It is reflected, first of all, in the greatest depths: maximum (average $28.9 \mathrm{~m})$, medium $(9.5 \mathrm{~m})$ and relative $(2.1 \mathrm{~m})$. Secondly, these lakes have one of the highest indices of lake basin permanence (1.85). These features mean the lakes are primarily in the initial stage of the evolution of their basins, and thus are much less susceptible to the secondary supply of suspended matter and biogenic compounds from the lake sediments.

The second group includes the lakes of the following Lakelands: Masurian, West Pomeranian and South Pomeranian (Fig. 3). The mean transparency of the lakes of these macroregions ranges from 1.99 to $2.11 \mathrm{~m}$ of the Secchi disc depth. Again, in these clusters of lakes the mean transparency is higher than the national mean. The observed differences between the mean transparency values calculated for the lakes of the Lithuanian Lakeland and the lakelands included in the second group (medium transparency), which were from $0.94 \mathrm{~m}$ (West Pomeranian Lakeland) to $1.06 \mathrm{~m}$ (South Pomeranian Lakeland), proved to be statistically significant $(\mathrm{p}<0.001)$.

The third group, i.e. the regions with the lakes of low water transparency, include the whole subprovince of South Baltic Coastlands with the Szczecin, Ko- 


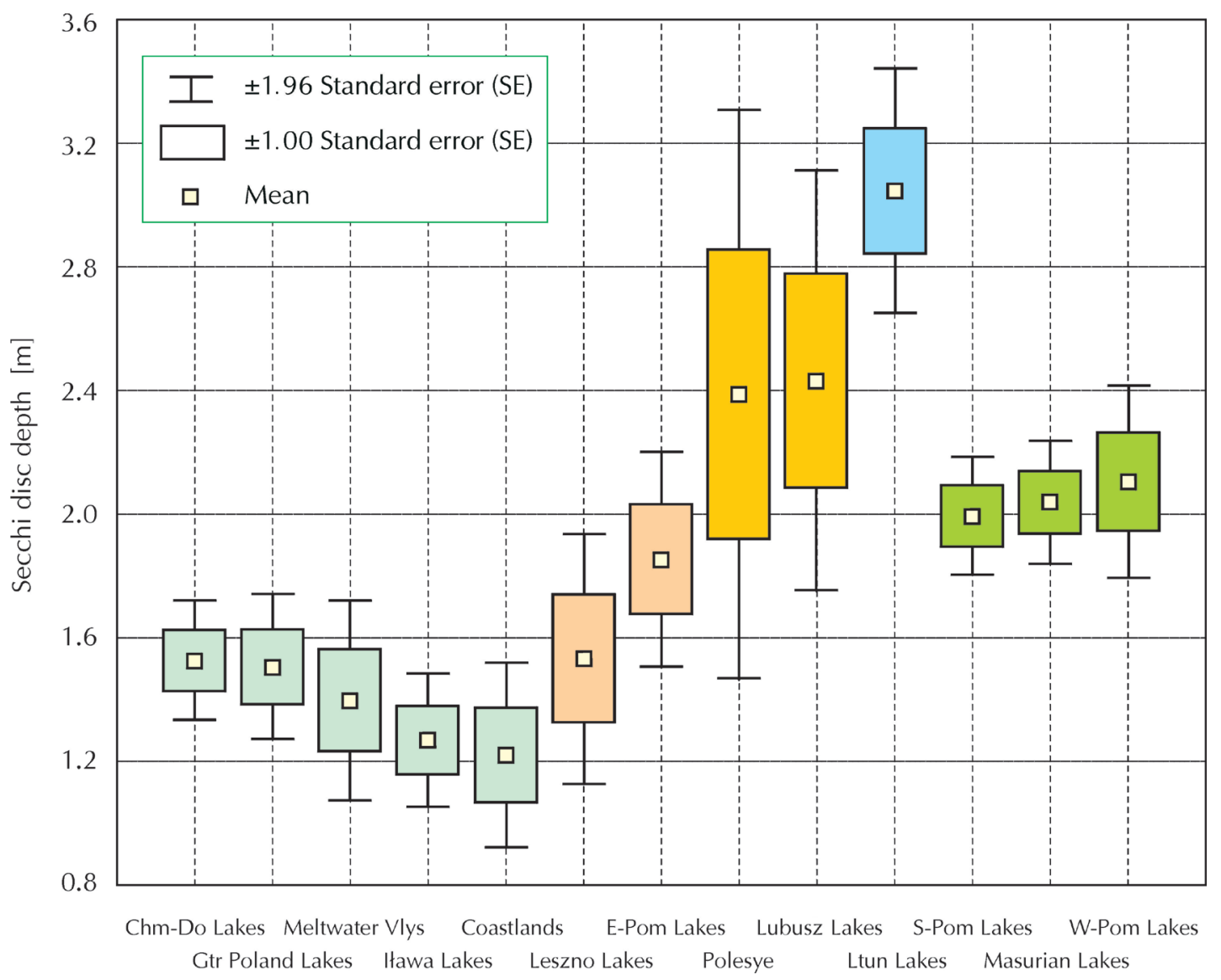

Fig. 3. Mean and standard error of the average water transparency of the lakes of the selected physico-geographical regions of Poland: Chełmno-Dobrzyń Lakeland (Chm-Dob Lakes), Greater Poland Lakeland (Gtr Poland Lakes), Toruń-Eberswalde Meltwater Valley and Varta-Oder Meltwater Valley (Meltwater Vlys), Iława Lakeland (Iława Lakes), Szczecin Coastland, Koszalin Coastland and Gdańsk Coastland (Coastlands), Leszno Lakeland (Leszno Lakes), East Pomeranian Lakeland (E-Pom Lakes), West Polesye (Polesye), Lubusz Lakeland (Lubusz Lakes), Lithuanian Lakeland (Ltun Lakes), South Pomeranian Lakeland (S-Pom Lakes), Masurian Lakeland (Masurian Lakes) and West Pomeranian Lakeland (W-Pom Lakes)

szalin and Gdańsk Coastlands, the Iława, ChełmnoDobrzyń and Greater Poland Lakelands, as well as the Toruń-Eberswalde and Varta-Oder Meltwater Valleys (Fig. 3). The mean transparencies in these lake clusters ranged from $1.22 \mathrm{~m}$ (Coastlands) to $1.52 \mathrm{~m}$ (Chełmno-Dobrzyń Lakeland). The differences between the mean calculated for the physicogeographical macroregions with lakes of low and medium water transparency were also found to be statistically significant, although the significance level was in this case a little lower $(\mathrm{p}<0.03)$.

A generalised picture of the observed relative differences in the transparency of the lakes of these three separate groups of macroregions is shown in Fig. 4. Other macroregions, not within any of the groups mentioned above, include lakes with very heterogeneous optical characteristics. The lakes of the
West Polesye and Lubusz Lakeland, with a mean depth of the Secchi disc of $2.40 \mathrm{~m}$ and a very high intraregional coefficient of transparency variation (0.700.74 ), occupy an intermediate position in relation to the lakes of the macroregions included in the first and second groups. Despite the distinct differences in their mean transparency with respect to the macroregions grouping lakes with high and medium transparency, reaching $0.30-0.60 \mathrm{~m}$, the analysis of the means did not indicate these differences were statistically significant. This is largely due to the substantial standard errors of the means calculated for the lakes of the Lubusz Lakeland $(0.35 \mathrm{~m})$ and West Polesye $(0.47 \mathrm{~m})$ resulting from the low number of lakes in both groups. Considering that the analysed data sets included from 85.7 to $100 \%$ of the elements from the general lake population (Table 1), it can be assumed that the cal- 


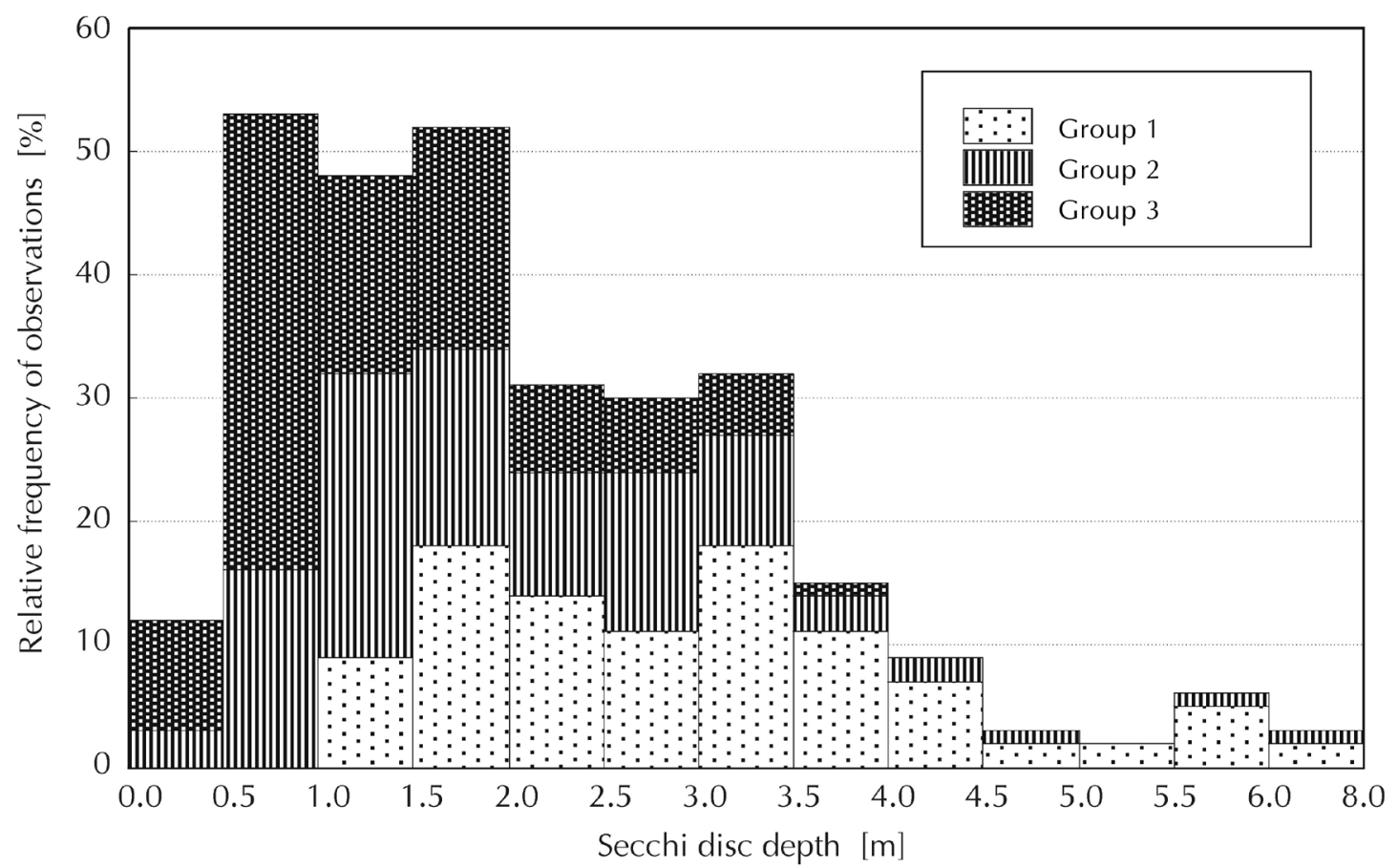

Fig. 4. Relative distribution of the frequency of the Secchi disc depth in the Polish lakes by macroregions of high (Group 1), medium (Group 2) and low (Group 3) water transparency. Actual frequencies were referred to the standard, constant number of lakes equalling 100 in each of the delimited groups

culated transparency means of these macroregion groups do not differ significantly or do not deviate at all from the mean values for all the lakes. Thus, the lakes of the both macroregions have a mean water transparency between those observed in the first and second groups. Similarly, the transient characteristic is revealed by the lakes of the East Pomeranian Lakeland and Leszno Lakeland. In the case of the lakes of these macroregions it can be concluded that the mean water transparency does not show significant differences with respect to the lakes of the second and third group, i.e. characterised by low and medium transparency. The differences between the average values do not exceed $0.65 \mathrm{~m}$.

The inter-regional diversity of water transparency, as outlined above, was also confirmed by the results of the variance analysis. The basic descriptive statistics of the lake water transparency of all the analysed macroregions and subprovinces are shown in Table 2.

\section{Discussion}

The concentration values of the basic forms of optically significant constituents present in inland waters (coloured dissolved organic matter, suspended solids) allows the studied lakes to be divided into three categories of lakes. This division is based on the indicators of water quality, which are the true colour of the water (TC) and the seston dry mass (SDM), and allows the division of lakes into those with clear water $\left(\mathrm{TC}<10 \mathrm{mg} \mathrm{Pt} \mathrm{dm}{ }^{-3}, \mathrm{SDM}<8 \mathrm{mg} \mathrm{dm}^{-3}\right)$, stained water $\left(\mathrm{TC}>10 \mathrm{mg} \mathrm{Pt} \mathrm{dm}{ }^{-3}, \mathrm{SDM}<8 \mathrm{mg} \mathrm{dm}^{-3}\right.$ ) and turbid water (TC $\left.<10 \mathrm{mg} \mathrm{Pt} \mathrm{dm}^{-3}, \mathrm{SDM}>8 \mathrm{mg} \mathrm{dm}^{-3}\right)$. The analysis of the water transparency diversity made for the above categories of lakes indicates that the Secchi disc transparency is largely shaped by the suspended particles present in the water, and to a lesser extent by dissolved organic matter (Koenigs and Edmundson 1991). The mean transparency of turbid lakes $(1.16 \mathrm{~m})$ is almost half the value of that of the stained lakes $(2.02 \mathrm{~m})$. The mean transparency of clear lakes is 2.92 $\mathrm{m}$. Similar correlations are observed also in relation to the median transparency calculated for each category of lakes (Fig. 5).

In most inland waters, almost all the light scattering is caused by the suspended matter contained in the water. The mineral tripton scatters the light strongly, but absorbs it weakly. Phytoplankton absorbs the sun radiation strongly but selectively (mainly in 
Table 2. Basic descriptive statistics of the Secchi disc transparency variability in lakes of various physicogeographical macroregions: SD - standard deviation, SE - standard error of the mean

\begin{tabular}{|c|c|c|c|c|c|c|c|}
\hline Region & Minimum & Maximum & Median & Midspread & Mean & SD & SE \\
\hline $\begin{array}{l}\text { Coastlands: } \\
\text { Gdańsk Coastland } \\
\text { Koszalin Coastland } \\
\text { Szczecin Coastland }\end{array}$ & 0.20 & 3.40 & 0.80 & $0.55-1.75$ & 1.22 & 0.93 & 0.15 \\
\hline $\begin{array}{l}\text { Meltwater Valleys: } \\
\text { Toruń-Eberswalde Meltwater Valley } \\
\text { Varta-Oder Meltwater Valley }\end{array}$ & 0.50 & 2.90 & 1.20 & $0.70-2.10$ & 1.40 & 0.72 & 0.16 \\
\hline West Pomeranian Lakeland & 0.30 & 5.75 & 2.00 & $1.15-2.70$ & 2.11 & 1.16 & 0.16 \\
\hline East Pomeranian Lakeland & 0.45 & 4.85 & 1.55 & $0.95-2.85$ & 1.86 & 1.11 & 0.18 \\
\hline South Pomeranian Lakeland & 0.40 & 7.15 & 1.80 & $1.10-2.90$ & 1.99 & 1.15 & 0.08 \\
\hline Iława Lakeland & 0.40 & 3.90 & 1.08 & $0.73-1.65$ & 1.27 & 0.70 & 0.11 \\
\hline Chełmno-Dobrzyń Lakeland & 0.60 & 3.45 & 1.40 & $0.90-1.95$ & 1.52 & 0.75 & 0.10 \\
\hline Lubusz Lakeland & 0.50 & 6.10 & 1.70 & $0.90-3.88$ & 2.43 & 1.70 & 0.35 \\
\hline Greater Poland Lakeland & 0.30 & 6.10 & 1.08 & $0.70-2.00$ & 1.51 & 1.16 & 0.12 \\
\hline Leszno Poland Lakeland & 0.50 & 3.80 & 1.20 & $1.00-1.90$ & 1.53 & 0.80 & 0.21 \\
\hline Lithuanian Lakeland & 1.10 & 7.20 & 2.95 & $1.95-3.73$ & 3.05 & 1.34 & 0.20 \\
\hline Masurian Lakeland & 0.50 & 6.50 & 1.80 & $1.20-2.70$ & 2.04 & 1.13 & 0.10 \\
\hline West Polesye & 0.50 & 6.00 & 1.95 & $1.25-3.00$ & 2.39 & 1.76 & 0.47 \\
\hline
\end{tabular}
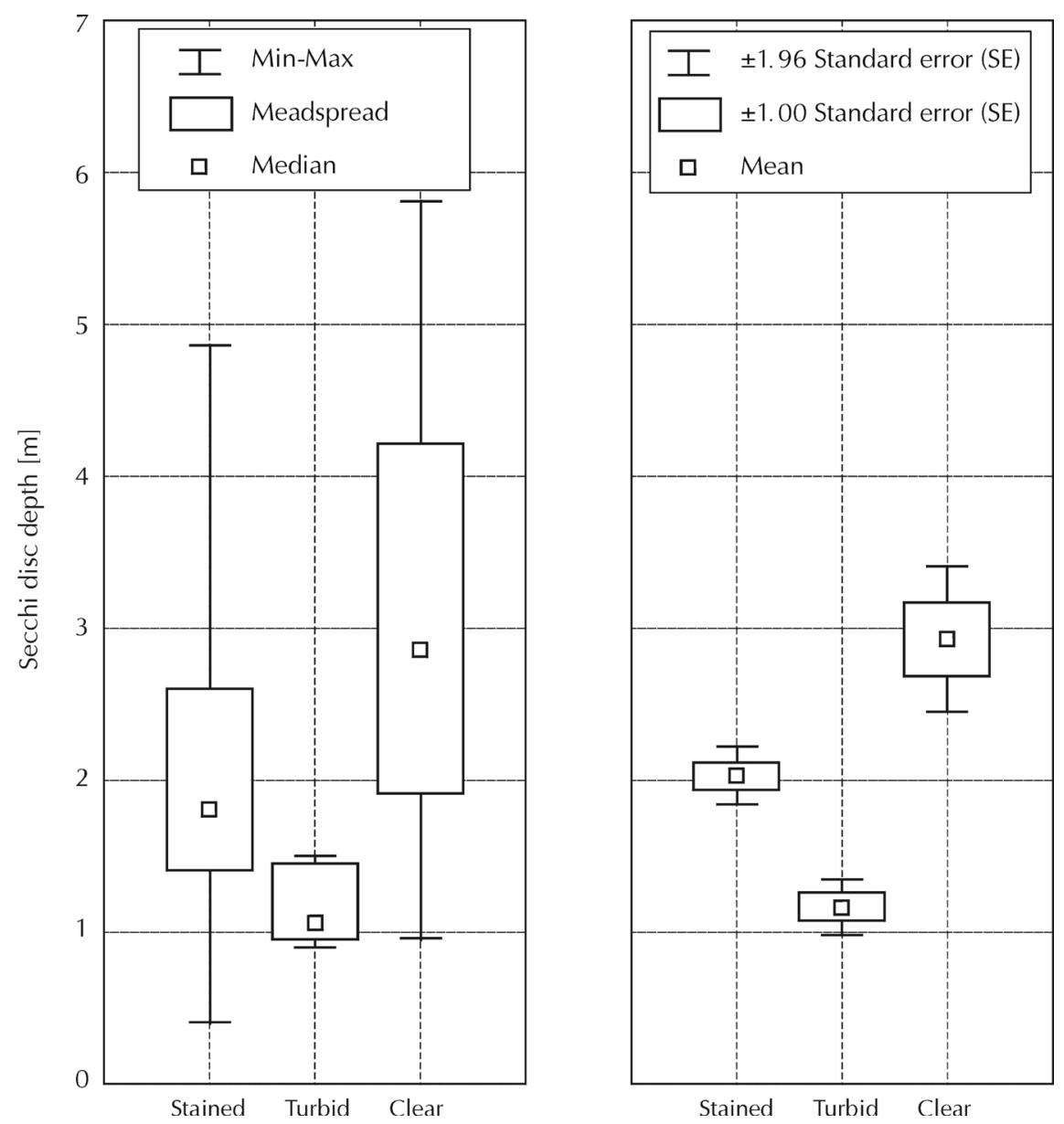

Fig. 5. The central tendency measures and variability measures of the water transparency by lake categories based on the true colour of the water and the seston dry mass 
terms of blue and red light) and at the same time is a factor strongly scattering it. The organic tripton in turn scatters the light and shows a spectral absorption similar to that characteristic of the dissolved coloured organic matter, which strongly absorbs ultraviolet radiation and visible radiation, especially in the short wave spectrum. In other words, the Secchi disc depth is primarily the function of light scattering, and to a lesser degree of its absorption.

Limnological practice and lake management often use empirical models which treat water transparency as a function of the concentration of chlorophyll $a$. The regression equations that define them are in practice very regional in nature and as such should not be uncritically transferred to areas other than those for which they were originally developed (Table $3)$. Phytoplankton, although a very important optical constituent of the water, is not the only admixture that shapes the optical properties of the lake waters. The relative impact of other constituents of water, which have the property of absorbing and/or scattering of light, on the Secchi disc depth, is shown in Fig. 6.
The regression lines are arranged clearly in two areas. The first area (lower) is enclosed by the lines (if $\ln$-ln transformed) of the directional coefficients (slopes) from -0.35 (Iława Lakeland) to -0.43 (Coastlands) and low values of the intercepts (1.26-1.48). The second area (upper) is limited by the regression lines with a slope in the range from - 0.41 (Lithuanian Lakeland) to -0.64 (Leszno Lakeland) and the intercept greater than 1.76. The lines in the lower area are more "flattened" and thus the unit phytoplankton biomass changes (concentrations of the chlorophyll $a$ pigment) will have a smaller impact on the water transparency. In that case, the impact of the suspensoids other than phytoplankton and/or the colour of water are very clearly indicated. These factors significantly worsen the light transmission conditions and thus water transparency. Even at the concentrations of chlorophyll $a$ corresponding to the state of ultraoligotrophy $\left(\sim 1.0 \mathrm{mg} \mathrm{m}^{-3}\right)$ in the lakes of the Iława Lakeland, or the lakes of the meltwater valleys or coastlands, the Secchi disc transparency is not greater than $4.50 \mathrm{~m}$. This observation is also confirmed by the empirical

Table 3. Regional regression models showing the correlation of the Secchi disc depth (SD) and the concentration of chlorophyll $a$ pigment $(\mathrm{Chl})$

\begin{tabular}{|c|c|c|c|c|}
\hline Formula & $R^{2}$ & $\mathrm{~N}$ & Region & References \\
\hline $\ln (S D)=2.04-0.68 \ln (C h l)$ & 0.86 & 147 & various lakes & Carlson (1977) \\
\hline $\ln (S D)=1.45-0.55 \ln (C h l)$ & 0.67 & 55 & Florida lakes & Brezonik (1978) \\
\hline $\ln (S D)=1.25-0.49 \ln (C h l)$ & 0.63 & 205 & Florida lakes & Canfield and Hodgson (1983) \\
\hline $\ln (S D)=1.75-0.44 \ln (\mathrm{Chl})$ & 0.53 & 17 & Masurian lakes & Kufel (1999) \\
\hline $\ln (S D)=1.90-0.51 \ln (C h l)$ & 0.76 & 102 & Estonian lakes & Milius and Starast (1999) \\
\hline $\ln (S D)=2.38-0.52 \ln (C h l)$ & 0.60 & 105 & Pomeranian lakes & Borowiak (2011) \\
\hline $\ln (S D)=1.96-0.50 \ln (\mathrm{Chl})$ & 0.65 & 657 & Polish lakes & this study \\
\hline $\ln (S D)=2.60-0.64 \ln (C h l)$ & 0.86 & 15 & Leszno Lakeland & $-" 1-$ \\
\hline $\ln (S D)=2.35-0.62 \ln (\mathrm{Chl})$ & 0.78 & 89 & Greater Poland Lakeland & $-" 1-$ \\
\hline $\ln (S D)=2.15-0.69 \ln (C h l)$ & 0.55 & 14 & West Polesye & $-" 1-$ \\
\hline $\ln (S D)=2.10-0.51 \ln (C h l)$ & 0.62 & 38 & East Pomeranian Lakeland & $-" 1-$ \\
\hline $\ln (S D)=2.08-0.51 \ln (C h l)$ & 0.63 & 133 & South Pomeranian Lakeland & $-"-$ \\
\hline $\ln (S D)=2.01-0.50 \ln (C h l)$ & 0.65 & 111 & Masurian Lakeland & $-" 1-$ \\
\hline $\ln (S D)=1.98-0.52 \ln (C h l)$ & 0.71 & 55 & Chełmno-Dobrzyń Lakeland & $-" 1-$ \\
\hline $\ln (S D)=1.97-0.53 \ln (C h l)$ & 0.76 & 24 & Lubusz Lakeland & $-" 1-$ \\
\hline $\ln (S D)=1.96-0.45 \ln (C h l)$ & 0.50 & 47 & West Pomeranian Lakeland & $-" 1-$ \\
\hline $\ln (S D)=1.76-0.41 \ln (C h l)$ & 0.75 & 39 & Lithuanian Lakeland & $-" 1-$ \\
\hline $\ln (S D)=1.48-0.41 \ln (C h l)$ & 0.59 & 19 & Meltwater Valleys & $-" 1-$ \\
\hline $\ln (S D)=1.32-0.43 \ln (\mathrm{Chl})$ & 0.47 & 33 & Coastlands & $-" 1-$ \\
\hline $\ln (S D)=1.26-0.35 \ln (C h l)$ & 0.48 & 40 & Iława Lakeland & $-" 1-$ \\
\hline
\end{tabular}




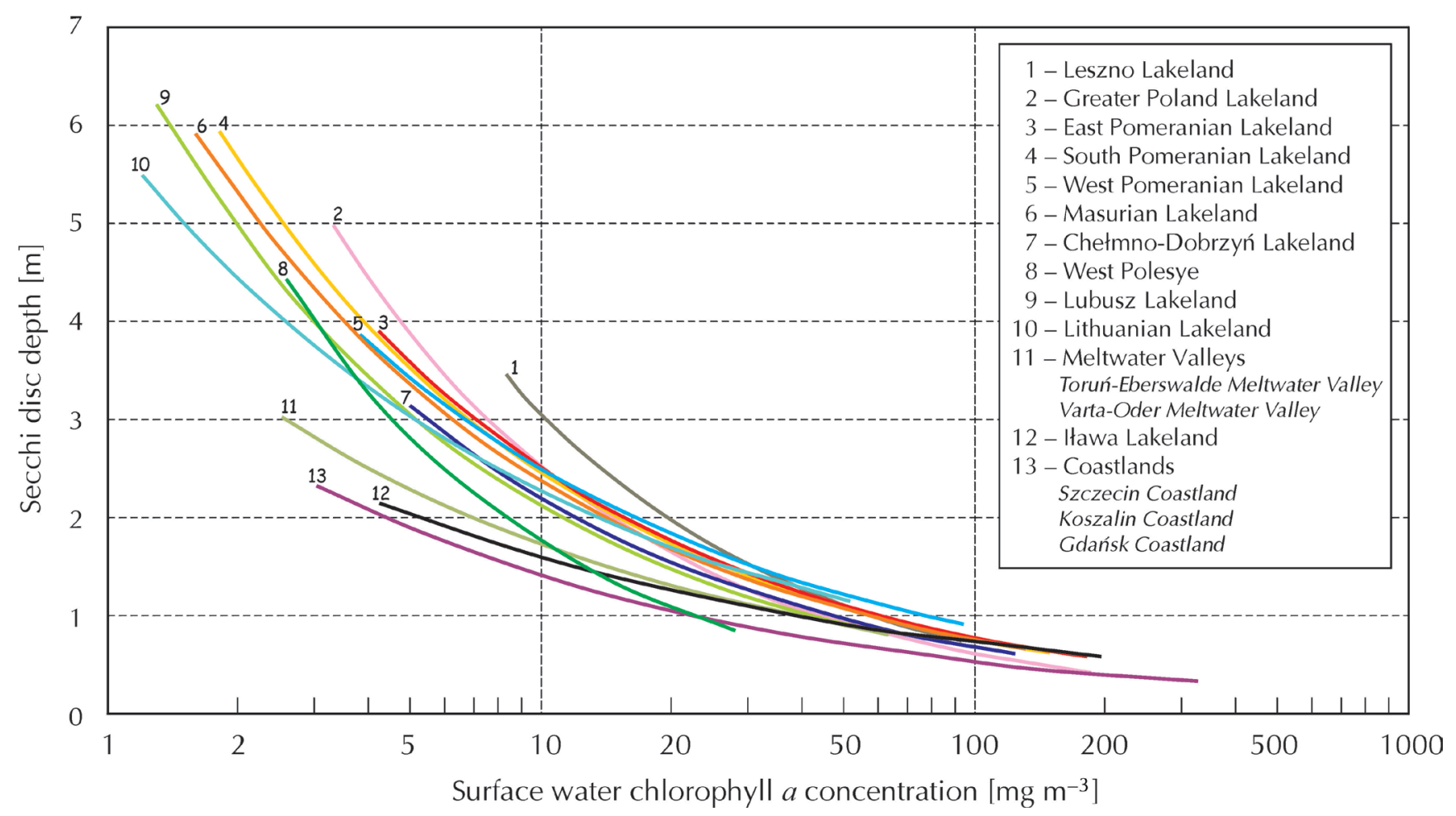

Fig. 6. Correlations between the Secchi disc depth and the chlorophyll $a$ concentrations observed in the Polish lakes by physicogeographical regions

data. The measured maximum water transparency of the lakes in these macroregions ranged from 2.90 to $3.90 \mathrm{~m}$ (Table 2). In addition, particularly at the low concentrations of the chlorophyll $a$ pigment $(<7.0$ $\mathrm{mg} \mathrm{m}^{-3}$ ), these lakes show much lower overall water transparency relative to the lakes of other regional units. Compared with the lakes of the macroregions described by the upper pencil of the regression lines these differences exceed one or more metres. The low water transparency is most of all influenced by the very high concentrations of humic substances and adverse morphometry of the lakes. The true colour of the water in these regions is the highest, and its average values range from 26 to $84 \mathrm{mg} \mathrm{Pt} \mathrm{dm}^{-3}$. They are also usually lakes of medium depth (Bogoslovskii 1960) which have a natural predisposition to the wind and the associated conditions for the development of hydrodynamic phenomena (openness index OI $>400$, relative depth $\mathrm{RD}<1 \%$ ). The amounts of the dissolved coloured organic matter in the waters of these lakes are also significantly affected by the specific location of these water bodies within such morphological forms as meltwater valleys and coastal alluvial plains characterised by a high percentage of wetlands and peaty areas.
The spread and the course of the regression lines grouped in the upper pencil of the curves also shows the varying degrees of the interaction between the water non-phytoplanktonic admixtures and the statistical relationship binding the water transparency with the concentration of chlorophyll $a$ (Fig. 6, Table 3 ). The positions of the regression lines show certain regional regularities. The extreme positions are taken by the ones that represent the empirical functions developed for the Leszno Lakeland (line 1) and the Lithuanian Lakeland (line 10). The external lines thus refer to the macroregions which, at the time of the recession of the ice sheet of the Vistulian Glaciation, were the first to be subjected to deglaciation $(20$ 000-18 800 yrs BP - Leszno Lakeland) and one of the last ones (16 200-14 500 yrs BP - Lithuanian Lakeland) (Fig. 7). The internal regression lines describing other macroregions refer chronologically to the main phases of the ice sheet's recession. As a result, they probably reflect the influence exerted by the physiographic characteristics of these regions formed by both the complex nature of the deglaciation (frontal deglaciation, areal deglaciation) as well as the whole complex of the following various morphological and hydrological processes of unequal duration. In that 


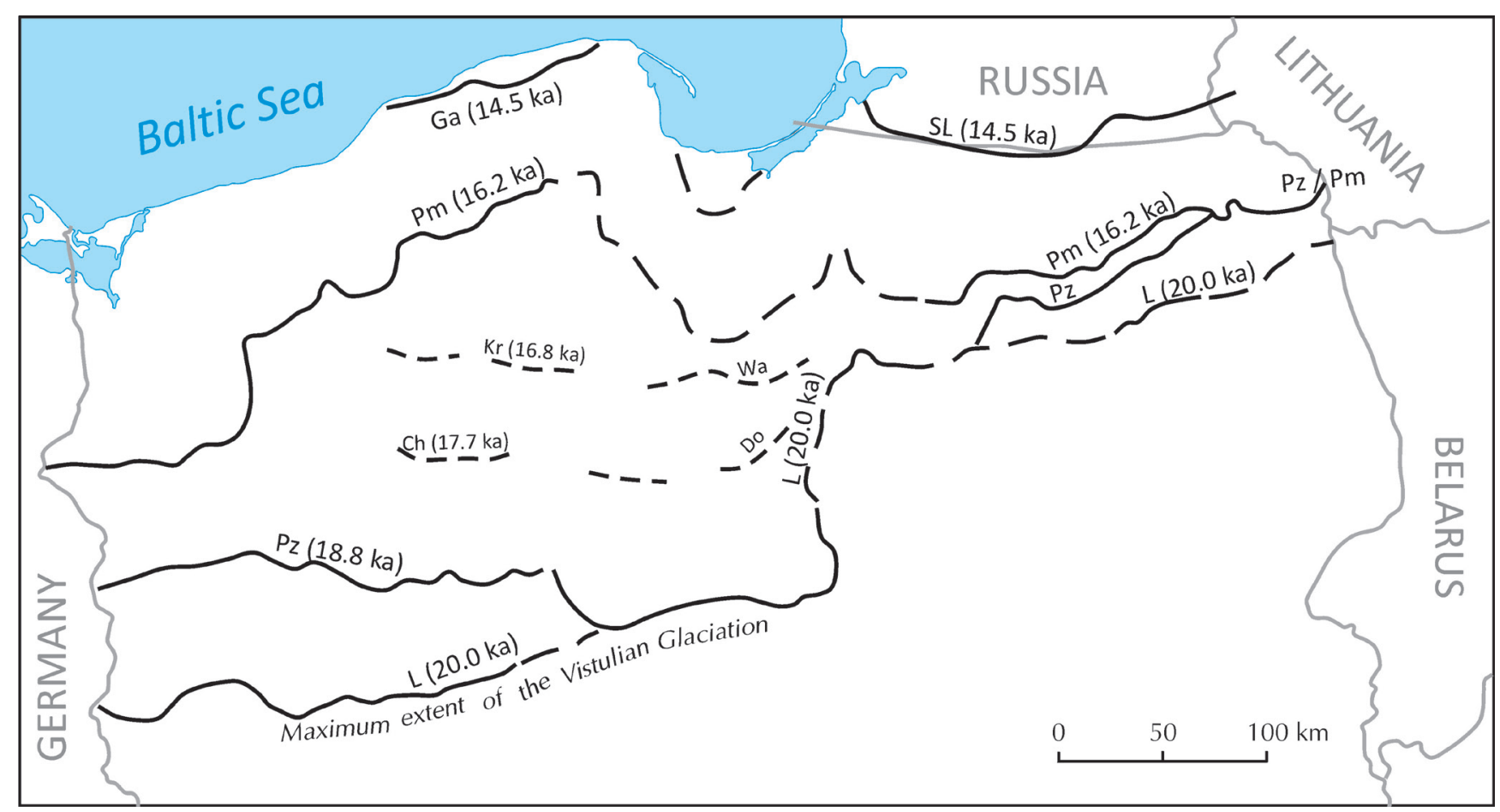

Fig. 7. Extention of the major phases and subphases during the Vistulian Glaciation in Poland and Lithuania: L - Leszno phase; Pz Poznań phase; Pm - Pomeranian phase; Ga - Gardno phase; SL - South Lithuanian phase; Ch, Do - Chodzież and Dobrzyń subphases; Kr, Wa - Krajna and Wąbrzeźno subphases (according to Wysota et al. 2002; Marks 2012)

case, the conditions of the formation and the degree of transformation of the young-glacial landscape can be considered as other factors determining the contemporary supply of the optically significant constituents to the lake.

The influence of the non-phytoplankton admixture in the water and the species composition of phytoplankton, often very significantly masking and modifying the actual relationship between the water transparency and the chlorophyll $a$ concentration, can also be seen by analysing lakes of different trophic state. Commonly used in limnological practice, also in Poland (Hillbricht-Ilkowska and Wiśniewski 1994; Marszelewski 2001; Kubiak 2003), are the indices of the trophic state based on the three formulas proposed by Carlson (1977). Underlying Carlson's method is the assumption that between the summer concentrations of chlorophyll $a$ (Chl), the Secchi disc depth (SD) and the concentration of total phosphorus (TP) there is a relatively close correlation. Though the highest priority in the classification is assigned to the partial index calculated from the concentrations of chlorophyll $a$, the trophic continuum was divided into units (0 to 100), which are based on the logarithmic transformation of the Secchi disc transparency. The observed differ- ences between the partial indices (TSI(Chl), TSI(TP), TSI(SD)) are therefore largely influenced by the variation of the entire complex of the optically significant constituents present in the lake water (Fig. 8), and not only one type of them, i.e. the phytoplanktonic suspension. Particularly large differences between the indices are found in the non-harmonic lakes, in which the light attenuation is dominated by the nonphytoplanktonic components, humic substances and tripton present in the water $(\mathrm{TSI}(\mathrm{Chl})<\mathrm{TSI}(\mathrm{SD})$ ) (Fig. 8: line 2). The lakes for which the relationship described by this regression line is true show the highest mean water colour $\left(68.7 \mathrm{mg} \mathrm{Pt} \mathrm{dm}^{-3}\right)$ and the highest mean concentration of the seston dry weight $(12.7 \mathrm{mg}$ $\mathrm{SDM} \mathrm{dm}^{-3}$ ). Equally important differences between the partial indices TSI(Chl) and TSI(SD), relative to the average conditions (Fig. 8: line T), are observed when the ecosystem of the lake is dominated by large particles or phytoplankton aggregates (small phytoplankton eaten by zooplankton, colonial forms of blue algae) (Fig. 7: line 1). The regression line 1 relating to those conditions is in turn typical for the water bodies with the mean water colour and the mean concentration of seston amounting to, respectively, $14.8 \mathrm{mg} \mathrm{Pt}$ $\mathrm{dm}^{-3}$ and $8.0 \mathrm{mg} \mathrm{SDM} \mathrm{dm}{ }^{-3}$. 


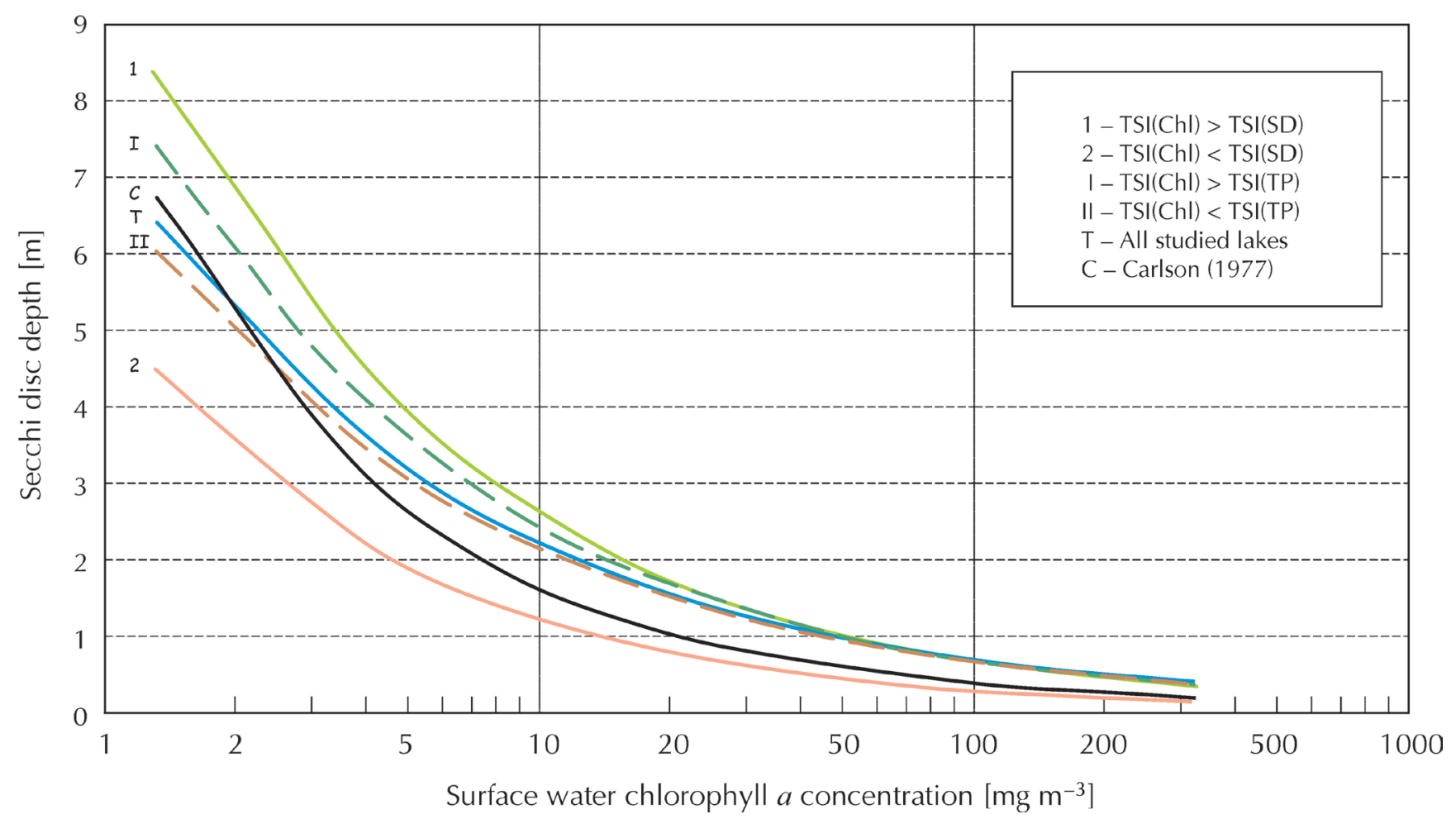

Fig. 8. Correlations between the Secchi disc depth and chlorophyll $a$ concentrations in lakes of various relations involving partial indicators of the trophic state based on Carlson's formulas (1977)

An important, albeit indirect, function in shaping the water transparency is played by the lake basin morphometry. The influence of the morphometry is most fully reflected in the impact of the depth conditions of the lake. Transparency varies in direct proportion to the changes in the mean and maximum depth. Thus, deep lakes have natural conditions conducive to the occurrence of higher water transparency than shallow water bodies (Table 4). This means that the internal processes going on in lakes (e.g. resuspension, internal supply) significantly affect the water transparency. The existence of a similar correlation between transparency and the average depth of lakes is revealed by the study conducted by Hakkanson (2004) in a group of Scandinavian lakes for which the coefficient of determination was $\mathrm{R}^{2}=0.46$ (log-log transformation). After the logarithmic transformation of the data collected for the Polish lakes and re-determining the strength of the correlation of transparency and mean depth, a very similar value of the coefficient of determination was obtained: $\mathrm{R}^{2}=0.41$, which reflects the relative stability of this correlation regardless of the existing external conditions. The remaining morphometric parameters and indices which influence the water transparency also include the relative depth of the lake (RD) and the index of the lake basin permanence (IBP). The first one describes the ratio of the fetch length (expressed as the square root of the surface of the water surface) to the maximum depth, while the second one reflects the influence of the littoral zone on the volume of the water body. Just as the average depth, both of these indices form internal transformation processes occurring in lakes.

Table 4. The Pearson linear correlation coefficients between the water transparency (Secchi depth) and the selected morphometric parameters and indices which describe the size and shape of the lake basins: surface area $(A)$, volume $(V)$, maximum depth $\left(D_{\text {max }}\right)$, mean depth $\left(\mathrm{D}_{\mathrm{m}}\right)$, depth index $\left(\mathrm{DI}=\mathrm{D}_{\mathrm{m}} / \mathrm{D}_{\max }\right)$, relative depth $\left(\mathrm{RD} 1=88.6 \mathrm{D}_{\max } / \mathrm{A}^{0.5}\right.$ and $\left.\mathrm{RD} 2=\mathrm{D}_{\max } / \mathrm{A}^{0.5}\right)$, openness index $\left(\mathrm{OI}=\mathrm{A} / \mathrm{D}_{\mathrm{m}}\right)$ and index of lake basin permanence (IBP $=\mathrm{V} / \mathrm{SL}, \mathrm{SL}-$ shore line). Values in bold denote the significance at $\mathrm{p}<0.05$

\begin{tabular}{cccccccccc}
\hline & $\mathrm{A}$ & $\mathrm{V}$ & $\mathrm{D}_{\max }$ & $\mathrm{Dm}$ & $\mathrm{DI}$ & $\mathrm{RD} 1$ & $\mathrm{RD} 2$ & $\mathrm{OI}$ & $\mathrm{IBP}$ \\
\hline Secchi depth & 0.029 & $\mathbf{0 . 1 8 5}$ & $\mathbf{0 . 5 5 6}$ & $\mathbf{0 . 5 7 7}$ & $\mathbf{- 0 . 2 8 5}$ & $\mathbf{0 . 5 0 5}$ & $\mathbf{0 . 5 0 4}$ & $\mathbf{- 0 . 2 8 0}$ & $\mathbf{0 . 4 0 3}$ \\
\hline
\end{tabular}




\section{Acknowledgements}

This research project was supported by a grant from the State Committee for Scientific Research, Poland (No. N N306 699940).

\section{References}

Arst H., Erm A., Herlevi A., Kutser T., Leppaeranta M., Reinart A., Virta J., 2008, Optical properties of boreal lake waters in Finland and Estonia, Boreal Environ. Res. 13(2): 133-158.

Birge E.A., Juday C., 1912, A limnological study of the Finger Lakes of New York, Bull. U.S. Bur. Fish. 27: 529-609.

Birge E.A., Juday C., 1933, The transparency, the color and the specific conductance of the lake waters of northeastern Wisconsin, Trans. Wis. Acad. Sci. Arts Lett. 28: 205259.

Bogoslovskii B.B., 1960, Schema gidrologicheskoi klassifikatsii ozer i raionirovanie ozer SSSR (Scheme of the hydrological classification of lakes and lakes zoning in the USSR), Vestnik Mosk. Univ., Ser. 5: Geografiia 2: 18-36 (in Russian).

Borowiak D., 2005, Visibility of Secchi disk in lakes of Eastern Pomerania: The role of chlorophyll $a$ and turbidity, Limnol. Rev. 5: 3-9.

Borowiak D., 2011, Właściwości optyczne wód jeziornych Pomorza (Optical properties of the Pomeranian lake waters), Wyd. UG, Gdańsk, p. 275 (in Polish, English summary).

Brezonik P.L., 1978, Effect of organic colour and turbidity on Secchi disc transparency, J. Fish. Res. Board Can. 35(11): 1410-1416.

Caffrey A.J., Hoyer M.V., Canfield D.E., 2007, Factors affecting the maximum depth of colonization by submersed macrophytes in Florida lakes, Lake Reserv. Manege. 23: 287-297.

Canfield D.E., Hodgson L.M., 1983, Prediction of Secchi disc depths in Florida lakes: Impacts of algal biomas and organic color, Hydrobiologia 99(1): 51-60.

Carlson R.E., 1977, A trophic state index for lakes, Limnol. Oceanogr. 22(2): 361-369.

Chambers P.A., Kalff J., 1985, Depth distribution and biomass of submersed aquatic macrophyte communities in relation to Secchi depth, Can. J. Fish. Aquat. Sci. 42(4):701-709.

Delebecque A., 1898, Les lacs français, Typographie Chamerot et Renouard, Paris, p. 436 (in French).

Dillon P.J., Rigler F.H., 1975, A simple method for predicting the capacity of a lake for development based on lake trophic status, J. Fish. Res. Bd. Can. 32(9): 1519-1531.

Edmondson W.T., 1980, Secchi disc and chlorophyll, Limnol. Oceanogr. 25(2): 378-379

Ekman S., 1915, Die Bodenfauna des Vattern, qualitativ und quantitativ untersucht, Int. Rev. Ges. Hydrobiol. Hydrogr. 7(4-5): 275-425 (in German).
Erlandsson C.P., Stigebrandt A., 2006, Increased utility of the Secchi disk to assess eutrophication in coastal waters with freshwater run-off, J. Marine Stst. 60(1-2): 19-29.

Ficek D., 2013, Właściwości biooptyczne wód jezior Pomorza oraz ich porównanie $\mathrm{z}$ właściwościami wód innych jezior i Morza Bałtyckiego (Bio-optical properties of waters in Pomeranian lakes and their comparison to optical properties of other lakes waters and the Baltic Sea), Rozpr. Monogr. 23/2013, PAN IO, Sopot, p. 351 (in Polish, English summary).

Forel F.-A., 1877, Étude sur les variations de la transparence des eaux du lac Léman, Arch. Sci. Phys. Nat. 59: 137

Forel F.-A., 1895, Le Léman. Monographie limnologique. Vol. 2, F. Rouge, Lausanne, p. 651 (in French).

Garbini A., 1897, Alcune notizie fisiche sulle acque del Benaco, Rivista Geogr. Ital. 4(3): 80-101 (in Italian).

Halbfass W., 1901, Beiträge zur Kenntnis der Pommerschen Seen, Peterm. Mitteil. Ergänzungsheft 136: 1-132 (in German).

Hassert K., 1912, Seenstudien in Nordkamerun, Zeitschr. Ges. Erdk. Berlin 1912(1/2): 7-41, 135-144 (in German).

Håkanson L., 2004, Lakes: Form and function, Blackburn Press, Caldwell, p. 201.

Hillbricht-Ilkowska A., Kajak Z., 1986, Parametry i wskaźniki przydatne do kontroli zmian zmian funkcjonalnych i strukturalnych w ekosystemach jeziornych ulegających procesowi eutrofizacji (Parameters and indices useful in controlling functional and structural changes in lakes undergoing eutrophication) [in:] Hillbricht-Ilkowska A. (ed.), Monitoring ekosystemów jeziornych (Monitoring of lake ecosystems), Ossolineum, Wrocław-Warszawa, p. 23-45 (in Polish, English summary).

Hillbricht-Ilkowska A., Wiśniewski R.J., 1994, Zróżnicowanie troficzne jezior Suwalskiego Parku Krajobrazowego i jego otuliny. Stan obecny, zmienność wieloletnia, miejsce w klasyfikacji troficznej jezior (Trophic diversity of the lakes of Suwałki Landscape Park and its buffer zone. Current state, long-term variability and place in the trophic classification of lakes), [in:] Hillbricht-Ilkowska A., Wiśniewski R.J. (eds) Jeziora Suwalskiego Parku Krajobrazowego. Związki z krajobrazem, stan eutrofizacji i kierunki ochrony (Lakes of the Suwałki Landscape Park. Links with landscape, eutrophication and protection measures), Zesz. Nauk. Kom. Nauk. PAN „Człowiek i Środowisko" 7: 181-200 (in Polish, English summary).

Jańczak J. (ed.), 1996, Atlas jezior Polski. T. 1: Jeziora Pojezierza Wielkopolskiego i Pomorskiego w granicach dorzecza Odry (Atlas of the Polish lakes. Vol. 1: Lakes of the Greater Poland and Pomeranian Lakelands within the Oder River drainage basin), Bogucki Wyd. Nauk., Poznań, p. 268 (in Polish).

Jańczak J. (ed.), 1997, Atlas jezior Polski. T. 2: Jeziora zlewni rzek Przymorza i dorzecza dolnej Wisły (Atlas of the Polish lakes. Vol. 2: Lakes of the Pomeranian river catchments and Lower Vistula River drainage basin), Bogucki Wyd. Nauk., Poznań, p. 256 (in Polish). 
Jańczak J. (ed.), 1999, Atlas jezior Polski. T. 3: Jeziora Pojezierza Mazurskiego i Polski południowej (Atlas of the Polish lakes. Vol. 3: Lakes of the Masurian Lakeland and southern Poland), Bogucki Wyd. Nauk., Poznań, p. 240 (in Polish).

Juday C., 1915, Limnological studies on some lakes in Central America, Trans. Wis. Acad. Sci. Arts Lett. 18: 214259.

KoenigsJ.P., Edmundson J.A., 1991, Secchi disk and photometer estimates of light regimes in Alaskan lakes: Effects of yellow color and turbidity, Limnol. Oceanogr. 36(1): 91-105.

Kondracki J., 2011, Geografia regionalna Polski (Regional geography of Poland), Wyd. PWN, Warszawa, p. 444 (in Polish).

Kubiak J., 2003, Największe dimiktyczne jeziora Pomorza Zachodniego. Poziom trofii, podatność na degradację oraz warunki siedliskowe ichtiofauny (The largest dimictic lakes of the West Pomerania. Trophic state, vulnerability to degradation, and ichthyofauna biotopic conditions), Rozpr. AR Szczec. 214, Wyd. AR, Szczecin, p. 96 (in Polish, English summary).

Kufel L., 1999, Dimictic versus polymictic masurian lakes: Similarities and differences in chlorophyll-nutrients-SD relationships, Hydrobiologia 408/409: 389-394.

Liburnau J.R., 1898, Der Hallstätter See. Eine limnologische Studie, Mittheil. Kais. Königl. Geogr. Ges. 41: 1-218 (in German).

Lityński A., 1926, Studja limnologiczne na Wigrach (Limnological studies in Lake Wigry), Arch. Hydrobiol. Ryb. 1(1-2): 1-78 (in Polish, German summary).

Luhtala H., Tolvanen H., 2013, Optimizing the use of Secchi depth as a proxy for euphotic depth in coastal waters: An empirical study from the Baltic Sea, ISPRS Int. J. Geo-Inf. 2: 1153-1168.

Marks L., 2012, Timing of the late Vistulian (Weichselian) glacial phases in Poland, Quater. Sci. Rev. 44: 81-88.

Marszelewski W., 2001, Jeziora Pojezierza Dobrzyńskiego (Lakes of Dobrzyńskie Lakeland), Wyd. UMK, Toruń, p. 139 (in Polish, English summary).

Meek S.E., 1908, The zoology of Lakes Amatitlan and Atitlan, Guatemala, with special reference to ichtiology, Field Columbian Museum Publ. 127, Zool. Ser. 7(6): 159-206.

Milius A., Starast H., 1999, Correlations between limnological variables of Estonian lakes, Proc. Estonian Acad. Sci. 48(2): 117-129.
Nordquist O., 1910, Über des Eindringen des Lichtes in von Eis und Schnee bedeckten Seen, Int. Rev. Ges. Hydrobiol. Hydrogr. 3(1-2): 79-83.

Padial A.A., Thomaz S.M., 2008, Prediction of the light attenuation coefficient through the Secchi disc depth: empirical modeling in two large Neotropical ecosystems, Limnology 9(2): 143-151.

Preisendorfer R.W., 1986, Sccchi disk science: Visual optics of natural waters, Limnol. Occanogr. 31(5): 909-926.

Sawicki L., Minkiewicz S., 1909, Sprawozdanie tymczasowe z badan jezior tatrzańskich (Interim report on the Tatra lakes studies), Okólnik Ryb. 108: 338-359 (in Polish).

Schindler D.W., 1971, Light, temperature, and oxygen regimes of selected lakes in the experimental lakes area, northwestern Ontario, J. Fish. Res. Bd. Can. 28: 157-169.

Stangenberg M., 1936, Szkic limnologiczny na tle stosunków hydrochemicznych Pojezierza Suwalskiego. Suchar i Jeziorko jako stadjum przejściowe zanikania jezior (Limnological study against the hydrochemical conditions of the Suwałki Lakeland. Lakes Suchar and Jeziorko as a transitional stage of lake disappearance), Pr. Inst. Bad. Lasów Państw. A 19: 1- 85 (in Polish, German summary).

Szaflarski J., 1936, Przeźroczystość i barwa wód jezior tatrzańskich (Transparency and colour of the Tatra lakes' waters), Wiad. Służby Geogr. 10(3): 387-394 (in Polish, German summary).

Tilzer M.M., 1988, Secchi disk - chlorophyll relationships in a lake with highly variable phytoplankton biomas, $\mathrm{Hy}$ drobiologia 162(2): 163-171.

Ule W., 1898, Beitrag zur physikalischen Erforschung der baltischen Seen, Forschungen zur deutschen Landesund Volkskunde 11(2): 21-72 (in German).

Ule W., 1901, Der Würmsee (Starnbergersee) in Oberbayern. Eine limnologische studie, Duncker \& Humbolt, Leipzig, p. 211 (in German).

Whipple G.C., 1899, The microscopy of drinking water, Wiley \& Sons, New York, p. 300.

Wysota W., Lankauf K.R., Szmańda J., Chruścińska A., Oczkowski H.L., Przegiętka K.R., 2002, Chronology of the Vistulian (Weichselian) glacial events in the Lower Vistula region, Middle-north Poland, Geochronometria 21: $137-142$

Zacharias O., 1896, Quantitative Untersuchungen über das Limnoplankton, Forschungsberichte aus der Biol. Station zu Plön 4: 1-64 (in German). 